Crop Breeding and Applied Biotechnology 12: 199-205, 2012

Brazilian Society of Plant Breeding. Printed in Brazil

\title{
ARTICLE
}

\section{The Inheritance of late blight resistance derived from Solanum habrochaites}

\author{
Ahmed Youssef Elsayed ${ }^{1 *}$, Derly José Henriques da Silva ${ }^{2}$, Pedro Crescêncio Souza Carneiro ${ }^{3}$ and Eduardo Seiti Gomide \\ Mizubuti $^{4}$
}

Received 05 December 2011

Accepted 22 August 2012

\begin{abstract}
Late blight caused by the oomycete Phytophthora infestans is a destructive disease of tomato in Brazil and other tropical and subtropical regions. The purpose of the present study was to analyses the inheritance of resistance to late blight and determine the genetic factors contributing to the resistance in the inbred line in '163A'. The Line '163A'resulted from interspecific cross between Solanum lycopersicum and $\mathrm{S}$. habrochaites $f$. glabratum. Inoculated field with mixture isolates of pathogen with 1000 spores $\mathrm{mL}^{-1}$ and naturally infested field trials showed that the expression of '163A' against multiple isolates of the pathogen was stable. The genetic analysis supported the hypothesis of two recessive genes controlling the resistance. The scaling test of additive-dominance model showed that is a good fit for the data confirming the absence or neglect of epistasis.
\end{abstract}

Key words: Solanum lycopersicum, Phytophthora infestans, recessive, inheritance.

\section{INTRODUCTION}

Tomato cultivars suffer from as many as 200 diseases worldwide of which 30 are routinely important. Out of these diseases, late blight, caused by the oomycete Phytophthora infestans Mont. De Bary, is a destructive disease of tomatoes and approximately $15-20 \%$ of fresh tomato production costs in Brazil are for late blight control (Mizubuti 2001). While worldwide losses due to late blight and control measures are estimated to exceed $\$ 5$ billion annually. The control of late blight heavily relies on the frequent application of protecting fungicides, which are applied every 5-14 days. Current control methods are low efficiency and have serious operational implementation constraints as high costs and labor demands. Late blight control is increasingly difficult due to high variability in P. infestans the introduction of new pathogen isolates, and increased resistance of the pathogen to fungicides (Kato et al. 1997). For clean tomato cultivation, using resistant cultivars is a desirable alternative to chemical control. The development of crops that possess durable genetic resistance provides the best prospect for efficient, economical and environmentally safe control of late blight (Mizubuti 2005, Bonnet et al. 2007).
In Brazil, the germplasm bank BGH (Banco de Germoplasma de Hortaliças), which belongs to Universidade Federal de Viçosa (UFV), has been established in 1960s. Currently this germplasm is incorporated in breeding programs for new varieties represents as germplasm source of cultivated species (Silva et al. 2001). The characterization of over than 350 tomato accessions of the BGH (http://www. bgh.ufv.br) resulted in define many resistance sources as well as to Tuta absoluta (Moreira et al. 2005, Oliveira et al. 2009), potyvirus (Zucchini yellow mosaic virus, ZYMV and Pepper yellow mosaic virus, PepYMV) (Moura et al. 2005, Juhász et al. 2008), whitefly (Bemisia tabaci biotype B) (Fernandes et al. 2009), Phytophthora infestans (Abreu et al. 2008) and geminivirus (Tomato yellow spot virus, ToYSV) (Aguilera et al. 2008).

Attempts to breed late blight resistant tomato lines resulting in the identification of three dominant genes: $P h-1$ on chromosome 7 (Clayberg et al. 1965), $P h-2$ on chromosome 10 (Moreau et al. 1998) and $P h-3$ on chromosome 9 (Chunwongse et al. 1998). Tomato varieties carrying the resistance genes $P h-1$ or $P h-2$ provide inadequate control against the local population of the pathogen (Cohen 2002).

\footnotetext{
${ }^{1}$ Agricultural Research Center, Horticulture Research Institute, Giza, Egypt. *E-mail: Ahmed.Elsayed@ufv.br

${ }^{2}$ Universidade Federal de Viçosa (UFV), Departamento de Fitotecnia, 36.570-000, Viçosa, MG, Brazil.

${ }^{3}$ UFV, Departamento de Biologia Geral

${ }^{4}$ UFV, Departamento de Fitopatologia
} 
While $P h-3$ gene, has been incorporated into many breeding lines of fresh market and processing tomato due to its efficacy against broad range of $P$. insfestans isolates. In recent study, the $P h-3$ gene showed highly stability under the field condition unlike $P h-1$ or $P h-2$ (Elsayed et al. 2011).

Race-specific and polygenic resistance have been characterized and exploited in breeding providing an efficient control of disease severity (Thabuis et al. 2004). The high variability in $P$. infestans populations throughout the world, especially for virulence, has made race-specific resistance genes almost useless in disease control (Andrivon 1994). With the lack of durability of resistance with single dominant genes that result in hypersensitive resistance (HR), it is probable that new resistance genes that result in HR will not be durable. More emphasis is being given to transfer of quantitative trait resistance to commercial cultivars of tomato. Resistance to late blight has also been observed in wild S. habrochaites (Kim and Mutschler 2000, Abreu et al. 2008). An interspecific $\mathrm{F}_{1}$ progeny (S. lycopersicum $\mathrm{L}$. cv. Santa Clara x S. habrochaites f. glabratum) accession BGH 6902 exhibited resistance to numerous P.infestans isolates under field conditions of Viçosa, MG state (Abreu et al. 2008). The purpose of the present study was to study the inheritance of resistance to late blight in the inbred line '163A' originated from the interspesific cross between $S$. lycopersicum L.cv. Santa Clara and Solanum habrochaites f. glabratum with investigate the possibility of new genes in Solanum habrochaites with recessive alleles that could be used in increase the resistance in the breeding programs under tropical highly humid conditions of Brazil.

\section{MATERIALS AND METHODS}

\section{Plant material}

The inbred ' $163 \mathrm{~A}$ ' is an advanced line that was originated from interspecific cross $S$. lycopersicum L.cv. Santa Clara x Solanum habrochaites f. glabratum. The '163A' obtained from successive generations of self-pollination and selection for late blight resistance program at the Department of Plant Science, Universidade Federal de Viçosa. The '163A' was crossed to the variety 'New Yorker' to obtain the $F_{1}$ seeds. The 'New Yorker' is susceptible variety possess the $P h-1$ resistance gene to late blight. In the following season, the $F_{1}$ plants were self-pollinated to obtain the $F_{2}$ seeds. The parents, $F_{1}$ and $F_{2}$ generations were grown during the winter of 2009 at the Experimental Field of Plant Science Department, Universidade Federal de Viçosa, located in the city of Viçosa (lat $20^{\circ} 45^{\prime} 14^{\prime \prime} \mathrm{S}$, long $42^{\circ} 52^{\prime} 53^{\prime \prime} \mathrm{W}$ and alt $648 \mathrm{~m}$ asl), Minas Gerais state.

\section{Pathogen isolates and preparation of inoculum}

To avoid both the specific-race resistance and possible epistatic effect of vertical resistance, mixture isolates of $P$. infestans collected from several regions of tomato production fields was applied. The $P$. infestans isolates were of the A1 mating type and belonging to US-1 clonal lineage. At early morning, infected leaves were collected from the commercial fields. These leaves were transferred in polyethylene cases kept under cold condition until reaching the laboratory. The infected leaves were placed in 30 x $40 \times 5 \mathrm{~cm}$ plastic trays in order to multiply the primary inoculum. A single ply of facial tissue paper was plastered with water on the bottom of the tray to maintain adequate humidity for inoculum development. The trays were kept in a dark chamber at $18-20{ }^{\circ} \mathrm{C}$ for $24 \mathrm{~h}$. After that, the surface of fresh mycelium on the underside of leaves was lightly brushed with a toothpick. The sporangia suspension was kept in the dark at $11-12{ }^{\circ} \mathrm{C}$ for $90-100$ min to release the zoospores (Nilson 2006). Uniform suspension was used to obtain an accurate sporangia count. The concentration was determined with a hemacytometer adjusted to $10^{3}$ sporangia $\mathrm{mL}^{-1}$. The inoculation was accomplished in June 2009 at 7:30 PM after about 2 hours of sunset using manual backpack sprayer (20 liter volume) applying $20 \mathrm{~mL}$ of the sporangia suspension per plant.

\section{Quantify the resistance}

Under the conditions of natural infection and artificial inoculation, the genotypes were screened against late blight. The first observation was recorded after 4 days of inoculation and then every 4 days during June 2009. The disease severity was recorded based on the proportion of area or amount of plant tissue showing the symptom. Provision of a thin film of water on the plants using micro sprinklers (full-circle $5 \mathrm{~m}, 325 \mathrm{ml} /$ mint/micro sprinkler) was applied asauxiliary condition for spore germination. The spray system was adjusted to turn on every 3 hours for 15 minutes over the day. The micro sprinklers were kept turned on for approximately 2 hours prior to field inoculation to provide a thin film of water to facilitate spore germination. The average maximum and minimum temperature was 25.2 and 13.7 ${ }^{\circ} \mathrm{C}$, respectively during disease development with average relative humidity $85.7 \%$.

\section{Data collection}

To evaluate the disease severity of late blight, the whole plant leaves were submitted to screening. It was best to record readings independently without knowing the value given at the previous reading at each date, such as having 
someone else write in the field book or by using a cassette recorder. The selection to the resistance to late blight was done based on the minimum values of severity at the end of epidemic $\left(\mathrm{Y}_{\max }\right)$.

\section{Data analysis}

Study of inheritance for resistance in a Mendelian approach was done by grouping plants into resistant, moderate resistant and susceptible classes. Three ratings were utilized in classification the resistance based on interval rang of the parents (Table 1) as (1) susceptible $71-100 \%$ severity; (2) moderate $31-70 \%$ and (3) resistant $0-30 \%$. Segregation ratios were tested for goodness-offit to theoretical ratios for the hypotheses that two genes recessive control the resistance. Chi-square $\left(\chi^{2}\right)$ test was performed on the segregating population using numerical data. Quantitative analysis to resistance was accomplished applying generation analysis $\left(\mathrm{P}_{1}, \mathrm{P}_{2}, \mathrm{~F}_{1}\right.$ and $\mathrm{F}_{2}$ generations $)$. Broad-sense heritability estimate $\left(\mathrm{H}^{2}\right)$ was obtained from the variance components of the variance estimates of $\mathrm{P}_{1}, \mathrm{P}_{2}, \mathrm{~F}_{1}$ and $\mathrm{F}_{2}$ (Mather and Jinks 1982). Narrow-sense heritability $\left(\mathrm{h}^{2}\right)$ was estimated by the formula, where $\mathrm{k}$ is the average degree of dominance in the cross. The use of this formula assumes no epistasis, no link among loci, equal gene effects for every loci. A scaling test for the additive-dominance model was performed with $t$-test of the parameter (4),, as indicated by Mather and Jinks (1984) with degree of freedom equal the number of individuals in $\left(\mathrm{F}_{2}+\mathrm{F}_{1}+\mathrm{P}_{1}+\mathrm{P}_{2}-4\right)$. Minimum number of genes controlling resistance was estimated by the Wright's minimum effective factors calculated with $\mathrm{F}_{2}$ generation data according to Cruz et al. (2004) formula where R is total amplitude in the $\mathrm{F}_{2}$ population and $\mathrm{V}_{\mathrm{G}}$ is the genetic variance in the $\mathrm{F}_{2}$. The means, variances, Chi-square test and other genetic parameters of the $\mathrm{Y}_{\max }$ were estimated using GENES software program (Cruz 2006).

\section{Results and Discussions}

Clear differences in severity among tomato genotypes were observed after inoculation with $P$. infestans under field conditions during winter 2009. Although laboratory methods can be used in resistance assay, the most effective and reliable methods are generally accepted to be natural infections or inoculated test plots under field conditions. After four days of the inoculation, the disease symptoms began to emerge slightly. In the following days, the heavy rains and low temperature stimulated disease development.

\section{Qualitative analysis}

The qualitative analysis of inheritance of resistance in the parents, offspring and $\mathrm{F}_{2}$ generations using test $\chi^{2}$ demonstrated that the goodness of fit of the $\mathrm{H}_{0}$ hypothesis that the qualitative genetic model $(9: 6: 1)$ of resistance to late blight is fit with probability of $28.46 \%$ (Table 1 ). Furthermore, the qualitative analysis showed the genetic model for the inheritance to resistance based on two recessive genes would be not discarded considering the genotypes (A-B-) as susceptible with presence of partial dominance for the susceptible parent. While the genotypes of (A-bb/aaB-) are moderate resistant and when the both alleles being recessive (aabb), exhibit resistant. The frequency distribution of the parents, $\mathrm{F}_{1}$ and $\mathrm{F}_{2}$ individuals showed that for the susceptible parent New Yorker, the severity ranged from 71 to $100 \%$ with majority (13 individuals) located in the $91-100 \%$ class. For the resistant parent $163 \mathrm{~A}$, the most individuals located in two classes ranged from 11 to $30 \%$ of severity. While the $\mathrm{F}_{1}$ generation the individuals were located in the susceptible class with the same range of susceptible parent but with less number of individuals in the final degree of susceptibility (10 plants). This distribution of the $\mathrm{F}_{1}$ individuals emphasizes the fact that the dominance of susceptibility over the resistance. Furthermore, the frequency distribution of the $\mathrm{F}_{2}$ individuals in three phenotypic classes of resistant, moderate resistant and susceptible with frequency of $10.10 \%$,

Table 1. Goodness of fit $(\chi 2$ and $P)$ for qualitative genetic model of resistance to late blight $(P$. infestans) in a population of a cross between the resistant '163A' and the susceptible 'New Yorker'

\begin{tabular}{|c|c|c|c|c|c|c|c|c|c|c|c|}
\hline \multirow{3}{*}{$\begin{array}{l}\text { Generation, } \\
1: 1 \text { tance to } \\
\text { TYLCD }\end{array}$} & \multirow{3}{*}{ Total } & \multicolumn{2}{|c|}{$\begin{array}{c}\text { Interval rang } \\
\text { (\% severity) }\end{array}$} & \multirow{2}{*}{\multicolumn{3}{|c|}{\begin{tabular}{|c|c|} 
Number of plants \\
Number of plants per symptom class*
\end{tabular}}} & \multicolumn{5}{|c|}{ Two recessive genes $(9: 6: 1)$} \\
\hline & & \multirow{2}{*}{ Min. } & \multirow{2}{*}{ Max. } & & & & \multicolumn{3}{|c|}{ Expected Numbers/ratio of the $\mathrm{F}_{2}$} & \multicolumn{2}{|c|}{ Goodness of fit } \\
\hline & & & & $\mathrm{S}$ & M & $\mathrm{R}$ & $\mathrm{S}$ & $\mathrm{M}$ & $\mathrm{R}$ & $\chi^{2}$ & $P$ \\
\hline New Yorker & 20 & 71 & 100 & 20 & -- & -- & -- & -- & -- & -- & -- \\
\hline $163 \mathrm{~A}$ & 19 & 17 & 30 & -- & -- & 19 & -- & -- & -- & -- & --- \\
\hline
\end{tabular}

"in the $\mathrm{F}_{1}$ generation, two plants had $35 \%$ and $44 \%$ of severity. The classes interval based on the susceptible and resistant parents rang (1) susceptible $71-100 \%$ severity; (2) moderate $31-70 \%$ and (3) resistant $0-30 \%$. 
Table 2. A genetic model for the inheritance of qualitative resistance against Phytophthora infestans in 163A inbred line based on two recessive genes

\begin{tabular}{lll}
\hline Genotype & Proportion & Phenotype \\
\hline A- B- & $9 / 16$ & Susceptible \\
\hline A- bb & $3 / 16$ & Moderate resistant \\
\hline aa B- & $3 / 16$ & Moderate resistant \\
\hline aa bb & $1 / 16$ & Resistant \\
\hline
\end{tabular}

Segregation ratio in $\mathrm{F}_{2}$ population $\mathrm{S}: \mathrm{M}: \mathrm{R}=9: 6: 1$

$36.36 \%$ and $53.53 \%$ respectively, revealed the existence of two different loci with recessive gene effect controlling the resistant in S. habrochaites. It worth to note that the moderate probability value $(28.46 \%)$ of $\chi^{2}$ test here could be in part due to the use of a rather relatively small population size or the possibility of including certain individual from one category to other as a result of the closed interval within the categories somewhat. To overcome this problem, it was modified the resistant category with interval 0-30 instead of 0-31 that considered previously discarding the individuals with abnormal values.

\section{Quantitative analysis}

The line ' $163 \mathrm{~A}$ ' showed fixed behavior regarding to resistance to late blight with average mean of $24 \%$ for $\mathrm{Y}_{\max }$. Whereas, the variety 'New Yorker' exhibited average mean of $92.59 \%$ for $\mathrm{Y}_{\max }$ as fully susceptible. The $\mathrm{F}_{1}$ individuals showed mean values of $\mathrm{Y}_{\max }$ closed to the susceptible parent with mean of $84.87 \%$ of $Y_{\text {max }}$ (Table 3), however they have the same interval of susceptible parent. The mean performance of $\mathrm{F}_{2}$ population decreased compared to their $\mathrm{F}_{1}$ generation in amount of $19.3 \%$ for $\mathrm{Y}_{\max }$ (Table 3). This result could be attributed to the effect of dominance toward the susceptibility (Table 4).

Table 3. The means and variances of the final severity $\left(\mathrm{Y}_{\text {max }}\right)$ for parents, $\mathrm{F}_{1}$ and $\mathrm{F}_{2}$ population inoculated with $P$. infestans and Joint scaling test of additive-dominance model

\begin{tabular}{lcccc}
\hline \multirow{2}{*}{ Generation } & \multicolumn{4}{c}{$\left(\mathrm{Y}_{\mathrm{Max}}\right)$} \\
\cline { 2 - 5 } & No of ind. & Mean & variance & $\mathrm{V}(\mu)$ \\
\hline $\mathrm{P}_{1}$ & 20 & 92.59 & 92.46 & 4.62 \\
\hline $\mathrm{P}_{2}$ & 19 & 24.00 & 23.018 & 1.15 \\
\hline $\mathrm{F}_{1}$ & 30 & 84.87 & 230.53 & 7.68 \\
\hline $\mathrm{F}_{2}$ & 99 & 67.75 & 40189.14 & 318.97 \\
\hline \multirow{2}{*}{ Scaling test } & $\mathrm{C}$ & $\mathrm{V} c$ & $t$-cal & $P$ \\
\cline { 2 - 5 } & -13.57 & 132.33 & -1.17964 & 23.80 \\
\hline
\end{tabular}

$\mathrm{Y}_{\mathrm{Max}}$ is the severity at the end of epidemic respectively, scale, $\mathrm{C}=4$ including $\mathrm{P}_{1}, \mathrm{P}_{1}, \mathrm{~F}_{1}$ and $\mathrm{F}_{2}$ generations, degree of freedom (167)
Table 4. The genetic parameters of the final severity $\left(\mathrm{Y}_{\max }\right)$ for the $\mathrm{F}_{2}$

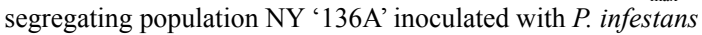

\begin{tabular}{lc}
\hline \multirow{2}{*}{ Parameters } & Disease trait \\
\cline { 2 - 2 } & $\mathrm{Y}_{\mathrm{Max}}$ \\
\hline Phenotypic variation & $605.9 \pm 84.84$ \\
\hline Environment variation & $144.1 \pm 21.96$ \\
\hline Genotypic variation & $461.8 \pm 92.21$ \\
\hline $\mathrm{H}_{\mathrm{b} . \mathrm{s}}(\%)$ & $76 \%$ \\
\hline $\mathrm{H}_{\mathrm{n} . \mathrm{s}}(\%)$ & $58 \%$ \\
\hline Heterosis & 44.34 \\
\hline Average degree of dominance & 0.77 \\
\hline Maximum value $\left(\mathrm{F}_{2}\right)$ & 100.00 \\
\hline Minimum value $\left(\mathrm{F}_{2}\right)$ & 15.00 \\
\hline Number of genes & $1.9 \approx 2.0$ \\
\hline
\end{tabular}

$\mathrm{H}_{\mathrm{b} . \mathrm{s}}$ and $\mathrm{H}_{\mathrm{n} . \mathrm{s}}$ are the heritability in broad sense and narrow sense, respectively

The heritability in broad $\left(\mathrm{H}_{\mathrm{b} . \mathrm{s}}\right)$ and narrow sense $\left(\mathrm{H}_{\mathrm{n} . \mathrm{s}}\right)$ was $76 \%$ and $58 \%$ for $\mathrm{Y}_{\max }$ revealed the magnitude of the environmental factors on the total variation. According to current model, the minimum number of genes controlling resistance was $1.9 \approx 2.0$ genes estimated by the Wright's minimum effective factors calculated with $\mathrm{F}_{2}$ generation (Table 4). This consistency with the previous finding resulted from the qualitative analysis demonstrate two recessive genes controlling the resistance in 163A. In spite of the resistant reported here controlled by tow genes, the low heritability observed here that often associated with quantitative traits, that could be attributed to the large interference of the environment factors on the expression of the trait studied (Ramalho et al. 2000). Similar finding was reported by Foolad et al. (2002) that demonstrated the heritability of resistant to early blight ranged from 65 to $71 \%$. In addition, the low heritability could be attributed to that the resistance measures by the severity is highly affect by the environmental factors, escape and subjective evaluation. Nevertheless, the results obtained from the qualitative analysis of inheritance coincide with the other quantitative analysis for resistance.

The estimated average degree of dominance was 0.77 for the severity at the end of epidemic trait indicating partial dominance, $0<\mathrm{d}<1$, revealed that the heterozygote $\left(\mathrm{F}_{1}\right)$ has a value that lies between the mean of the two homozygotes parents but toward the susceptible one. While in the qualitative analysis, the individuals of heterozygote $\left(\mathrm{F}_{1}\right)$ have lies in the same susceptible parent categories indicating complete dominance. This slight discrepancy in the degree of dominance estimated through the two approaches could be attributed to the fact that in the qualitative approach, is based on numerical classes and treats with them individu- 
ally in contrast to quantitative approach that the genetic parameters are resulted from the means and variances of each generation. This type of resistance that is associated with reduction in the time course of development of symptoms is desirable trait for plant breeder since it is often effective across a broad range of pathogen races or strains (Parlevliet 1979). The average degree of dominance towards the susceptibility indicates partial recessive gene action controlled the resistant. Whereas, the inheritance of resistance to other pathogens such as Ralstonia solanacearum, and Colletotrichum coccodes in tomato are quantitative with partial dominance of the alleles in tandem with the higher AUDPC (Neto et al. 2002, De Castro et al. 2007).

This wide range of severity values observed among homogenous plants of the resistant and susceptible parents indicate that the resistance to $P$. infestans is affected by environmental factors. Similar expression was recorded by the homogenous-heterozygous $\mathrm{F}_{1}$ plants $(\mathrm{AaBb})$ that their severity ranged from 75 to $100 \%$ scored as susceptible. Similar findings were reported by Irzhansky and Cohen (2006) that found $\mathrm{F}_{1}$ plants exhibited various levels of moderate resistance and $F_{2}$ plants segregated 3:6:7 as resistant: moderately resistant: susceptible, respectively. Their data supported the hypothesis that race-non-specific resistance in S. pimpenellifolium L3707, is controlled by two independent genes but partially-dominant and dominant epistatic effect. While the resistance in '136A' was recessive with partial dominance for susceptibility. The average degree of dominance is estimated as the square root of the average squared degree of dominance. The averaging is over all loci and over all heterozygotes possible at each locus. In this method, each squared degree is weighted according to the frequency of the heterozygote and according to the squared difference between the genetic values of the corresponding two homozygotes. Possible biases in the average degree of dominance were previously discussed. Nonetheless, other factors such as the bias due to different signs of individual degrees of dominance, to epistasis and to linkage could be affect the estimation of this parameter.

It is noteworthy that previous studies demonstrated that the current tomato line derived from the interspecific cross is a good source of resistance to a range of $P$. infestans infecting tomato in Brazil (Fiorini et al. 2010). Therefore, our results strongly emphasize the potential interest of ' $136 \mathrm{~A}^{\text {' }}$ and related lines as donors of broad-spectrum resistance for late blight control in tomato breeding programs. Evidence for the stability of the resistance described here under extremely high induced and natural late blight infection pressure was provided. Interestingly, in these conditions symptoms could appear in plants of inbred lines.
The genetic analysis of resistance demonstrated that two major recessive loci control the resistance to late blight in ' $163 \mathrm{~A}$ '. Recessive resistance has been associated with the lack of factors/functions needed for pathogen infection. Therefore, we could hypothesize that the plant host factor needed for an effective interaction of the pathogen is altered in the resistant inbred line tested here. Quantitative analysis also suggested the involvement of at least one more locus in the resistance and scale test of additive-dominance model for the both disease variables predict the predominance of this model of gene effect for resistance to late blight tested here (Table 3 ). The relatively simple mode of inheritance and fairly high heritability described here makes feasible introgression of the resistance from line ' $163 \mathrm{~A}$ ' into tomato commercial varieties. These genes have to be selected for during each round of backcrossing including progeny test after every singular generation of backcross (e.g., $\mathrm{BC}_{1}, \mathrm{BC}_{3}$, $\mathrm{BC}_{5}$ ) to select the individuals that have the recessive alleles controlling the resistance. In addition, the use of molecular markers could reduce the size of populations since only homozygous plants would require further screening. This could increase breeding efficiency and reduce screening costs.

The similar level of severity observed between the $F_{1}$ and the New Yorker parent indicates that at least two dominant genes are involved in the higher level of pathogen susceptibility. Furthermore, the 9:6:1 segregation ratio of the $F_{2}$ progeny suggests that the resistant found in the 163A line requires a homozygous recessive genotype at two genes other than the non-segregation $P h-3$ gene, and these additional genes not linked to $P h-3$. Is it well-known, the most useful resistance to late blight reported to date is provided by the $P h-3$ gene derived from $S$. chilense (Miranda et al. 2010, Elsayed et al. 2011), which is not stable under high disease pressures but present minor frequency of resistance overcame $(25.8 \%)$ compared to $P h-1,(88.7 \%)$ and $P h-2$, (64.5\%) (Miranda et al. 2010). However the $P h-3$ gene exhibited fixed resistance against the current isolates of southern of Brazil region (Elsayed et al. 2011).

Furthermore, combining both resistant genetic make up could provide more efficient late blight control. However, it should be noted that this kind of resistance could be effective through pyramiding both dominance and recessive genes that could be reduce incidence in nature as restricted $P$. infestans in plants at least until reaching the unfavorable condition that might reduce pathogen availability. Thus, based on our data, a lower risk of late blight spread is expected by using the resistance shown here because reduced primary inoculum spread is expected because of a lower propensity of plants to be infected. Therefore, the tomato line described here could be a valuable source of 
resistance to late blight. Based on our finding, suggesting new genes in Solanum habrochaites with recessive alleles ph-6 and ph-7 controlling the resistant to late blight in the inbred line '163A', originated from the interspecific cross S. lycopersicum L.cv. Santa Clara x Solanum habrochaites f. glabratum.

\section{ACKNOWLEDGMENT}

The authors are grateful to the Conselho Nacional de Desenvolvimento Científico e Tecnolgico (CNPq) and to the Academy of Science for the Developing World (TWAS( for financial support.

\section{Herança da resistência a requeima derivada de Solanum habrochaites}

Resumo - Requeima causada por Phytophthora infestans é uma doença destrutiva de tomate no Brasil e em outras regiões tropicais e subtropicais. O objetivo do estudo foi o de analisar a herança da resistência à requeima e determinar os fatores genéticos que contribuem para a resistência na linhagem '163A'. A linhagem '163A'resultou de cruzamento interespecifico entre Solanum lycopersicum $e \mathrm{~S}$. habrochaites $f$. glabratum. As plantas foram avaliadas por infecção natural e por inoculação com uma mistura de isolados do patógeno com 1000 esporângios $m L^{-1}$. A expressão de '163A' contra múltiplos isolados do patógeno foi estável. A análise genética suportou a hipótese de dois genes recessivos controlando a resistência. O teste do modelo aditivo-dominante mostrou bom ajuste para dados que confirmam a ausência ou negligenciam epistasia.

Palavras-chave: Solanum lycopersicum, Phytophthora infestans, recessivo, herança.

\section{REFERENCES}

Abreu FB, Silva DJH, Cruz CD and Mizubuti ESG (2008) Inheritance of resistance to Phytophthora infestans (Peronosporales, Pythiaceae) in a new source of resistance in tomato (Solanum sp.). Genetics and Molecular Biology 31: 493-497.

Aguilera JG, Alves JM, Elsayed AY, Flores MP, Silva DJH and Zerbini FM (2008) Screening forresistance to Tomato yellow spot virus (ToYSV) in tomato (Lycopersicon esculentum Mill.) germplasm using two methods of inoculation. Egyptian Journal of Agricultural Research 86: $1207-1216$.

Andrivon D (1994) Race structure and dynamics in populations of Phytophthora infestans. Canadian Journal of Botany 72: 1681-1687.

Bonnet J, Danan S, Boudet C, Barchi LP, Caromel B, Palloix A and Lefebvre V (2007) Are the polygenic architectures of resistance to Phytophthora capsici and P. parasitica independent in pepper. Theoretical and Applied Genetics 115: 253-264.

Chunwongse J, Chunwongse C, Black L and Hanson P (1998) Mapping of the $\mathrm{Ph}-3$ gene for late blight from $L$. pimpinellifoliumL3708. Report of the Tomato Genetics Cooperative 48: 13-14.

Clayberg CD, Butler L, Rick CM and Robinson RW (1965) List of tomato genes of January 1965. Report of Tomato Genetics Cooperative 15: 7-21.

Cohen Y (2002) Populations of Phytophthora infestans in Israel underwent three major genetic changes during 1983 to 2000. Phytopathology 92: 300-307.

Cruz CD (2006) Programa Genes: versão windows - aplicativo computacional em genética e estatística. Editora UFV, Viçosa, 648p.

Cruz CD, Regazzi JA and Carneiro PCS (2004) Divergência genética. In Cruz CD, Regazzi JA and Carneiro PCS (eds.) Modelos biométricos aplicados ao melhoramento genético. Editora UFV, Viçosa, p. 377-413.
De Castro AP, Diez MJ and Nuez F (2007) Inheritance of Tomato yellow leaf curl vírus resistance derived from Solanum pimpinellifolium UPV16991. Plant Disease 91: 879-885.

Elsayed AY, Silva DJH, Mizubuti ESG and Carneiro PCS (2011) Combining the monogenic and polygenic resistant genes to late blight in tomato. Journal of Plant Breeding and Crop Science 3: 251-259.

Fernandes MES, Silva DJH, Fernandes FL and Picanço MC (2009) Novos acessos de tomateiro resistentes à mosca branca biótipo B. Pesquisa Agropecuária Brasileira 44: 1545-1548.

Fiorini CVA, Silva DJH, Mizubuti ESG, Barros JS, Silva LJ, Milagres C and Zaparoli MR (2010) Caracterização de linhagens de tomateiro originadas de cruzamento interespecífico quanto à resistência à requeima. Horticultura Brasileira 28: 197-202.

Foolad MR, Subbiah P and Ghangas GS (2002) Parent-offspring correlation estimate of heritability for early blight resistance in tomato, Lycopersicon esculentum Mill. Euphytica 126: 291-297.

Irzhansky I and Cohen Y (2006) Inheritance of resistance against Phytophthora infestans in Lycopersicon pimpenellifolium L3707. Euphytica 149: 309-316.

Juhász ACP, Silva DJH, Zerbini FM,Carneiro PCS, Soares BO and Cruz CD (2008) Base genética da resistência de um acesso de tomate silvestre ao mosaico-amarelo do pimentão. Pesquisa Agropecuária Brasileira 43: 713-720.

Kato M, Mizubuti ES, Goodwin SB and Fry WE (1997) Sensitivity to protectant fugicidies and pathogenic fitness of clonal lineages of Phytopthora infestans in the United States. Phytopathology 87: 973-978.

Kim MJ and Mutschler MA (2000) Differential response of resistant lines derived from the L. pimpinellifolium accession L3708 and L.hirsutum accession LA1033 against different isolates of Phytophthora infestans in detached leaf lab assays. Report of the Tomato Genetics Cooperative 50: 23-25. 
AY Elsayed et al.

Mather K and Jinks JL (1982) Biometrical Genetics. $3^{\text {rd }}$ ed., Chapman and Hall, London.

Miranda BEC, Suassuna ND and Ailton Reis (2010) Mating type, mefenoxam sensitivity, and pathotype diversity in Phytophthora infestans isolates from tomato in Brazil. Pesquisa Agropecuária Brasileira 45: 671-679.

Mizubuti ESG (2001) Requeima ou mela da batata e do tomate. In Luz EDMN, Santos AF, Matsuoka K and Bezerra JL Doenças causadas por Phytophthora no Brasil. Rural Campinas, São Paulo, p. 100-174.

Mizubuti ESG (2005) Custo da requeima. Cultivar - Hortaliças e Frutas 32: 23-26.

Moreau P, Thoquet P, Olivier J, Laterrot H and Grimsley N (1998) Genetic mapping of $\mathrm{Ph}-2$, a single locus controlling partial resistance to Phytophthora infestans in tomato. Molecular Plant-Microbe Interact 11: 259-268.

Moreira G, Silva DJH, Picanço MC, Peternelli LA and Caliman FRB (2005) Divergência genética entre acessos de tomateiro infestados por diferentes populações da traça do tomateiro. Horticultura Brasileira 23: 893-898.

Moura MCCL, Zerbini FM, Silva DJH and Queiroz MA (2005) Reação de acessos de Cucurbita sp. ao Zucchini yellow mosaic virus (ZYMV). Horticultura Brasileira 23: 206-210.
Neto AFL, Silveira MA, Souza RM, Nogueira SR and André CMG (2002) Inheritance of bacterial wilt resistance in tomato plants cropped in naturally infested soils of the state of Tocantins. Crop Breeding and Applied Biotechnology 2: 25-32.

Nilson HE (2006) Bioassay to detect small differences in resistance of tomato to late blight according to leaf age, leaf and leaflet position, and plant age. Australasian Plant Pathology 35: 297-301.

Oliveira FA, Silva DJH, Leite GLD, Jham GN and Picanço M (2009) Resistance of 57 greenhouse-grown accessions of Lycopersicon esculentum and three cultivars to Tutaa bsoluta (Meyrick) (Lepidoptera: Gelechiidae). Scientia Horticulturae 119: 182-187.

Parlevliet J E (1979) Components of resistance that reduce the rate of epidemic development. Annual Review of Phytopathology 17: 203-222.

Ramalho M, santos J B and Pinto CABP (2000) Genética na agropecuária. $2^{\text {nd }}$ ed., UFLA, Lavras, 472p.

Silva DJH, Moura MC and Casali VW (2001) Recursos genéticos do banco de germoplasma de hortaliças da UFV: histórico e expedições de coleta. Horticultura Brasileira 19: 108-114.

Thabuis A, Lefebvre V, Bernard G, Daube`ze AM, Phaly T and Pochard E (2004) A phenotypic and molecular evaluation of a recurrent selection program for a polygenic resistance to Phytophthora capsici in pepper. Theoretical and Applied Genetics 109: 342-351. 